\title{
1 Sex and estrous cycle affect experience-dependent plasticity in mouse primary
} 2 visual cortex

\section{Authors}

Rachel W. Schecter ${ }^{*}$, Cambria M. Jensen ${ }^{1 *}$, and Jeffrey P. Gavornik ${ }^{1}$

\section{Institutional Affiliations}

${ }^{1}$ Biology Department, Boston University, Boston, MA

*Authors contributed equally to the work

Corresponding author: Jeffrey P. Gavornik, gavornik@bu.edu

\section{Abstract}

Sex hormones can affect cellular physiology and modulate synaptic plasticity, but it is not always clear whether or how sex-dependent differences identified in vitro express themselves as functional dimorphisms in the brain. Historically, most experimental neuroscience has been conducted using only male animals and the literature is largely mute about whether including female mice in will introduce variability due to inherent sex differences or endogenous estrous cycles. Though this is beginning to change following an NIH directive that sex should be included as a factor in vertebrate research, the lack of information raises practical issues around how to design experimental controls and apply existing knowledge to more heterogeneous populations. Various lines of research suggest that visual processing can be affected by sex and estrous cycle stage. For these reasons, we performed a series of in vivo electrophysiological experiments to characterize baseline visual function and experience-dependent plasticity in the primary visual cortex (V1) of male and female mice. We find that sex and estrous stage have no statistically significant effect on baseline acuity measurements, but that both sex and estrous stage have can modulate two mechanistically distinct forms of experience dependent cortical plasticity. We also demonstrate that resulting variability can be largely controlled with appropriate normalizations. These findings suggest that V1 plasticity can be used for mechanistic studies focusing on how sex hormones effect experience dependent plasticity in the mammalian cortex.

\section{Acknowledgements}

36 We thank Mike Baum for his advice in designing these experiments, and Lisa Stowers and

37 Sandeepa Dey for their advice and technical support related to estrous staging. We are grateful to

38 Elizabeth de Laittre for technical support. 
Introduction

In May of 2014, the NIH released a directive that sex must be factored into research of vertebrate

41 animals (Clayton and Collins, 2014). In support of the NIH statement, Shansky and Woolley

42 advise researchers to "accept [sex differences] as part of a complex physiological background"

43 of each animal (Shansky and Woolley, 2016). This statement minimizes the impact that

44 variability associated with a heterogeneous "physiological background" could have on

45 neuroscience research, where a variety of factors that can affect brain function - handling, cage

46 mate socialization, etc. - are difficult to measure and control. Unlike other fields of biology,

47 systems-level neuroscience research often lacks valid ex vivo models that could mitigate these

48 factors. Neuroscientists have been hesitant to include female animals in their research since sex

49 chromosomes and gonadal hormones represent two sources of potentially serious variance. Some

50 have raised concerns that the broad inclusion of female animals in preclinical experiments will

51 not produce desired outcomes but may have unintended consequences of "wasting resources,

52 slowing down research or even provoking a backlash” ds(Fields, 2014; Richardson et al., 2015).

53 As a consequence of these considerations, there is a 5:1 bias towards male-only neuroscience

54 studies, the highest in all fields measured (Beery and Zucker, 2011).

Brain research must overcome this experimental inertia both as a practical matter (i.e. to

56 comply with the NIH directives) and to address substantive critiques of building biological

57 science around male animals alone. A major hurdle is the assumption that the estrous cycle

58 introduces variability in both behavioral and physiological measures of neural function (Mogil

59 and Chanda, 2005). While several recently published meta-analyses suggest this concern may be

60 overblown in rodents (Prendergast et al., 2014; Becker et al., 2016; Fritz et al., 2017), there is

61 also good reason to take this concern seriously: chromosomal and hormonal effects do lead to 
62 clear differences between females and males that can be seen at multiple levels and can impact a

63 variety of functions including cognitive and emotional responses, learning and memory, and

64 degree of severity in a variety of neurological disorders resulting from injury or pathology (Jazin

65 and Cahill, 2010; McCarthy et al., 2012).

Plasticity experiments are particularly susceptible to hormonal cycle influences due to the

67 variety of receptor types and signaling cascades that can be altered by fluctuating

68 neuromodulator activity. For example, estrogen modulates NMDAR subunit expression in the

69 hippocampus (Gazzaley et al., 1996; Cyr et al., 2001), changes spine density (Gould et al., 1990;

70 Woolley and McEwen, 1992), and can enhance LTP (Warren et al., 1995; Scharfman et al.,

71 2003). While there is scant direct evidence for or against sexual dimorphism in sensory cortices,

72 estrogen has been demonstrated to modulate spine density in the imprecisely defined

73 "sensorimotor cortex" (Chen et al., 2009) and nitric oxide synthase knockout in primary

74 somatosensory cortex affects experience-dependent plasticity in male but not female animals

75 (Dachtler et al., 2012). Sex differences in V1 have not been directly demonstrated in vivo, but

76 there are several reasons to expect they exist. Human studies have shown that various aspects of

77 visual perception correlate with fluctuating estrogen levels over the menstrual cycle, including

78 visual memory and spatiotemporal processing (Phillips and Sherwin, 1992; Penton-Voak et al.,

79 1999; Resnick and Maki, 2001). In vitro animal work has demonstrated that neuromodulators

80 can fundamentally change the form of LTP/LTD induction curves in V1 neurons (switching, for

81 example, whether a particular stimulation pattern results in LTP or LTD) (Huang et al., 2012;

82 Huang et al., 2013), 7 $\alpha$-Estradiol can promote experience-dependent plasticity in rat V1

83 (Sengupta et al., 2019), and mouse V1 is sensitive to estrogen (Jeong et al., 2011) which plays a

84 role in V1 homeostatic plasticity (Gao et al., 2017). These findings highlight the importance of 
85 determining whether sex and estrous cycles impact V1 function in vivo. One thing to note is that

86 nearly all of the work linking estrogen to plasticity was performed in vitro or by artificially

87 administering estrogen to gonadectomized animals. As such, the literature provides essentially

88 no information on the extent to which endogenous sex-based variations exist in sensory cortex or

89 how to control for them if they exist.

90 For all these reasons, we set out to quantify the impact of sex and endogenous hormone

91 fluctuations caused by the estrous cycle on baseline function and experience-dependent plasticity

92 in the primary visual cortex. We measure no significant difference in visual acuity limits

93 between male and female animals. We find that sex has no significant effect on a form of spatial

94 coding called stimulus-selective response potentiation (SRP) (Frenkel et al., 2006; Cooke and

95 Bear, 2012), but it does affect spatiotemporal sequence potentiation (Gavornik and Bear, 2014).

96 We also tracked estrous cycling in a parallel set of experiments conducted exclusively in female

97 mice and determined that estrous stage has no impact on our measurements of physiological

98 function but can modulate plasticity coding both spatial and spatiotemporal information. Our

99 results show that these effects can be effectively controlled for in some circumstances using in-

100 group normalization and suggest mouse V1 as an in vivo model system to study how sex

101 hormones affect mechanistically distinct forms of cortical plasticity and learning.

102

103 Materials and Methods

104

105 Mice

106 All procedures involving laboratory animals occurred at Boston University and adhered to the

107 guidelines of the National Institutes of Health and were approved by the Institutional Animal 
108 Care and Use Committee at BU, Boston, MA, USA. Mice were housed in groups of 2-5

109 separated by sex with food and water available ad libitum and maintained on a 12-hour light-

110 dark cycle. All animals were C57BL6 WT ordered from Charles River or C57BL6 WT progeny

111 of heterozygous breeding pairs of VGAT-ChR2-EYFP transgenic mice (Jax stock \#014548),

112 Thy1-GCaMP6f transgenic mice (Jax stock \#024276), or DAT-IRES-CRE transgenic mice (Jax

113 stock \#006660), genotyped by Transnetyx using real-time PCR for the EYFP, EGFP, and CRE

114 genes, respectively; only animals which lacked transgene expression and tested positive for the

115 corresponding WT control were used in experiments.

\section{Estrous staging}

118 For estrus/diestrus grouped experiments: female mice 8 weeks and older were analyzed daily as

119 described in (Dey et al., 2015). Animals were encouraged to grip onto the cage lid with their

120 front forepaws and held at the base of the tail with the thumb and forefinger, using the middle

121 and ring fingers loosely flanking the mouse's torso underneath the rib cage. Direct cytology was

122 performed with tissue collected via vaginal lavage of fifteen microliters of sterile PBS, and wet

123 mount slides were examined with phase contrast microscopy. Smears were classified (with

124 reference to (Byers et al., 2012) as follows: estrus - a predominance of cornified epithelial cells,

125 metestrus - a mix of cornified epithelial and leukocyte cells, diestrus - a predominance of

126 leukocyte cells, and proestrus - a predominance of nucleated epithelial cells (see Figure 2).

127 Once mice had completed at least one cycle through all four stages and were at the height of

128 either estrus (100\% cornified cells) or diestrus $(100 \%$ leukocyte cells) they were included in

129 experimental groups as yoked pairs. 
131 VEP Surgery

132 Electrode implantation followed the procedures used in previous studies (Porciatti et al., 1999;

133 Sawtell et al., 2003). Mice were first injected with $0.1 \mathrm{mg} / \mathrm{kg}$ Buprenex sub-cutaneously to

134 provide analgesia. They were then anesthetized with $1.5-3 \%$ isoflurane. The scalp was shaved

135 and cleaned with iodine and $70 \%$ ethanol before an incision was made to expose the skull. A

136 steel head post was affixed to the skull anterior to bregma using cyanoacrylate glue. Burr holes

$137(<0.5 \mathrm{~mm})$ were then drilled in the skull over binocular V1 (3.0 mm lateral of lambda). Tapered

138 tungsten recording electrodes (FHC, Bowdoinham, ME, US), $75 \mu \mathrm{m}$ in diameter at their widest

139 point, were implanted in each hemisphere $450 \mu \mathrm{m}$ below the cortical surface to target

140 thalamocortical recipient layer 4. Silver wire (A-M systems, Sequim, WA, US) was placed in the

141 cerebrospinal fluid over prefrontal cortex to serve as an electrical reference. Mice were allowed

142 to recover for at least 48 hours prior to initial head-fixation.

144 In vivo electrophysiology

145 VEP recordings were conducted in awake, head-restrained mice. Prior to recording, mice were

146 habituated to the restraint apparatus in situ in front of a gray screen for a 30-minute session on

147 each of two consecutive days. All data was amplified and digitized using the commercially

148 available OmniPlex recording system (Plexon Inc., Dallas TX). Data was acquired at $25 \mathrm{kHz}$ and

149 local field potentials (LFPs) were down-sampled to 1-kHz utilizing a 500-Hz low-pass anti-

150 aliasing filter. Data was extracted from the binary storage files and analyzed using custom

151 software written in C++ and Matlab (MathWorks, Natick, MA, all stimulus generation and

152 analysis code is available for download at https://gavorniklab.bu.edu/supplemental-

153 materials.html). Each animal was implanted with an electrode in both the left and right 
154 hemisphere. When electrodes produced a clear and comparable VEPs bilaterally, both

155 hemisphere's responses were averaged together. Otherwise, we used data from the hemisphere

156 with the largest VEP (in all cases, the same hemisphere was used for all recording sessions).

157 VEPs were quantified by algorithmic scoring of the peak-to-peak voltage swing following a

158 visual stimulus event. Sequence magnitudes are defined as the average peak-to-peak response

159 magnitude for the second and third elements of the sequence, either B-C (trained) or C-B

160 (novel).

162 Stimulus delivery

163 Visual stimuli were generated with custom software written in Matlab using the PsychToolbox

164 extension (http://psychtoolbox.org) to control stimulus rendering and timing. A 27-inch

165 widescreen monitor (Acer XB270HU) was positioned $20 \mathrm{~cm}$ in front of the mouse and centered

166 so as to occupy the entire binocular region of visual space. Visual stimuli consisted of full-field

167 sinusoidal grating utilizing the full range of monitor display values between black and white,

168 with gamma-correction to ensure constant total luminance in both gray-screen and patterned

169 stimulus conditions. For acuity experiments, animals were exposed to 200 phase reversals at

170 each spatial frequency. Phase reversals occurred every 0.5 secs. SRP experiments used a grating

171 with spatial frequency of 0.05 cycles per degree. A single "familiar" orientation was presented

172400 times on each training day, and a "novel" orientation was interleaved with the familiar

173 stimulus on the test day. In Sequence Learning experiments, a sequence consisted of four

174 elements of a full-screen, $100 \%$ contrast sinusoidal grating at 0.05 cycles per degree (each held

175 on screen for $150 \mathrm{~ms}$ ), followed by an inter-sequence gray period lasting $1.5 \mathrm{sec}$. Sequence

176 elements differed by a minimum of 30 degrees and order was restricted to prevent the 
177 appearance of rotation. During training, a single sequence was presented 200 times per day in

178 four blocks of 50 presentations with each block separated by $30 \mathrm{sec}$. On the test day, blocks of a

179 novel sequence (DCBA) were interleaved with the trained (ABCD) sequence.

182 All experiments comparing male and female mice were conducted using yoked littermates and

183 blind to sex (though physical differences between male and female mice are sometimes

184 apparent). Due to variations in stage onset and duration, it was not possible to fully yoke

185 experimental groups in experiments addressing the effects of estrous cycling. These experiments

186 were conducted on cage-mate animals, with staging and experiments occurring in parallel as

187 much as possible. In all experiments, data was analyzed blind using a single common scoring 188 algorithm.

All data are shown using population-averaged VEPs (e.g., the average stimulus-locked

190 LFP) and violin plots of quantified VEP magnitudes. The shape of each violin indicates a kernel

191 density estimates of the data (produced using the ksdensity function in Matlab's statistical

192 toolbox) with mean values and data quartiles marked. To facilitate accurate comparisons, all

193 violins on each individual plot were produced using a single bandwidth parameter chosen as the

194 average of optimal values calculated for each individual data set on that plot. Statistical $n$ values

195 reported indicate the number of individual animals in each experimental group. SPSS was used

196 for parametric statistical analysis. Unless otherwise noted, 2-way ANOVAs were used to

197 determine the statistical impact or either sex or estrus stage on stimulus evoked VEP potentiation

198 as a function of either training day or stimulus type and the Shapiro-Wilk test was used to

199 confirm data normality. When main effects were significant, pairwise comparisons were 
200 performed using the independent two-tailed t-test with Bonferroni correction for multiple

201 comparisons. The sizes of experimental cohorts were planned based on previously published

202 experiments and our own experience indicating 5-10 animals are required in each cohort to reach

203 statistical significance with adequate power. We used post-hoc estimates to verify that all

204 statistically significant effects had an observed power $\geq 0.8$ for $\alpha=0.05$ (true in all cases unless

205 otherwise noted). In all cases, we planed the experiment using the minimum number of mice

206 expected to be required to achieve significant results based on our expectation of attrition rates

207 and effect sizes. Animals were excluded from the experiment only for electrode failure or as

208 described in the text.

$210 \quad$ Results

211 Female and male mice have comparable visual acuity which is unaffected by estrous cycle

212 Our first set of experiments were designed to establish whether genomic differences during

213 development result in any baseline functional differences in visual responsiveness between adult

214 male and female mice. Visually evoked potentials (VEPs, calculated as the average stimulus-

215 locked local field potential response) recorded in V1 can be used to assess visual function in

216 mice and produce a quantitative metric that matches behavioral measures of visual acuity

217 (Prusky and Douglas, 2003; Cooke et al., 2015). Adult (P67) female and male littermate mice

218 were implanted with VEP recording electrodes in layer 4 of binocular primary visual cortex, a

219 depth that yields the maximum negative going VEP (Huang et al., 1999; Sawtell et al., 2003).

220 Head-fixed animals were shown phase reversing sinusoidal gratings with 8 spatial frequencies

221 between 0.05 and 0.7 cycles per degree (Figure 1A). As the spatial frequency increases, the

222 magnitude of evoked potentials decreases (Porciatti et al., 1999) and the point at which the VEP 
223 asymptotes at the level of fluctuations recorded during gray-screen viewing identifies the upper

224 limit of visual acuity (Figure 1B). While there is a clear and expected effect of stimulation

225 spatial frequency on VEP magnitude $\left(F_{7,200}=56.03, p<0.001\right)$, this metric revealed no statistical

226 difference between the visual acuity of female $(n=11)$ and male $(n=16)$ mice $\left(F_{1,200}=1.96\right.$,

$227 p=0.16)$ nor any interaction between sex and acuity $\left(F_{7,200}=1.14, p=0.34\right)$.

228 We next repeated the acuity measurement in females to determine whether estrous cycle

229 has a statistical effect on visual responsiveness, grouping female mice based on cytology of

230 vaginal leukocyte and epithelial content (Figure 2). We found that cycling occurred every 6-12

231 days in an irregular and unpredictable manner (Table 1), with often rapid progressions though

232 metestrus and proestrus that would make it difficult if not impossible to design multi-day

233 plasticity experiments reliably occurring during specific stages of the cycle across yoked cohorts.

234 Visual acuity was assessed at the peak of estrus $(n=9)$ and diestrus $(n=10$, Figure 1B). As with

235 sex, there was a highly significant effect of spatial frequency $\left(F_{7,136}=60.44, p<0.001\right)$ but

236 measured no acuity differences between estrus and diestrus $\left(F_{1,136}=0.564, p=0.45\right)$ and no

237 significant interaction of the within and between animal factors $\left(F_{7,136}=0.825, p=0.57\right)$.

239 Sex effects experience dependent plasticity

240 Having established that there is no statistical difference in baseline visual physiology of either

241 sex or estrous stage, we next attempted to determine whether sex modulates experience-

242 dependent cortical plasticity. Stimulus-selective response potentiation (SRP) is a form of visual

243 learning induced by daily presentations of a visual stimulus of a particular orientation (Frenkel et

244 al., 2006; Cooke and Bear, 2010; Cooke et al., 2015). SRP is easily characterized by a significant

245 potentiation of VEPs elicited by familiar stimuli and provides a robust measure of underlying 
synaptic plasticity. This potentiation occurs over days and is selective for the spatial parameters

247 of the stimulus used to induce it. SRP requires NMDAR signaling that results in AMPAR

248 insertion at the synapse (Frenkel et al., 2006) and employs the mechanism of long-term synaptic

249 potentiation (LTP) (Cooke and Bear, 2010) including in parvalbumin-positive interneurons

250 (Kaplan et al., 2016). As mentioned above, these elements have been identified as potential

251 mechanistic correlates of sex-dependent plasticity and might be expected to cause measurable

252 plasticity differences between male and female mice.

Following the standard VEP implantation surgery, adult (approximately P67) littermate

254 mice were presented with a phase-reversing $0.05 \mathrm{cy} /{ }^{\circ}$ sinusoidal grating stimulus rotated to $45^{\circ}$

255 every day for 5 days (Figure 3A). On the 5th day of the SRP experiment, the mice were also

256 presented with a novel stimulus constructed by rotating the familiar stimulus to a new angle

$257\left(135^{\circ}\right)$. In accord with previous experiments, we found that VEP amplitudes evoked by the

258 familiar visual stimulus increased significantly across presentation days in both male $(n=16)$ and

259 female $(n=11)$ mice (Figure 3B-C, $\left.F_{4,125}=51.39, p<0.001\right)$, but there was no main effect of sex

$260\left(F_{1,125}=1.57, p=0.21\right)$ or significant interaction $\left(F_{4,125}=1.622, p=0.173\right)$. To isolate the effects of

261 potentiation, statistics were calculated using VEP score normalized relative to in-group average

262 response magnitudes on day 1, though the same conclusions follow if statistics are calculated

263 using raw VEP values instead (data not shown, Day: $F_{4,125}=48.84, p<0.001$; Sex: $F_{1,125}=3.37$,

$264 p=0.07$; Sex $*$ Day: $F_{4,125}=0.81, p=0.52$ ). VEPs evoked on day 5 by the novel stimulus were

265 significantly smaller than those evoked by the familiar stimulus in both male and female mice

$266\left(F_{1,50}=93.19, p<0.001\right)$, there was a small but significant effect of $\operatorname{sex}\left(F_{1,50}=4.35, p=0.04\right)$ and no

267 significant interaction $\left(F_{1,50}=0.365, p=0.55\right)$. The effect of sex on day-5 familiar/novel 
comparisons was moderate and relatively low power with these group sizes $\left(\eta_{\mathrm{p}}{ }^{2}=0.08\right.$, observed power $=0.53)$.

SRP encodes spatial features of a visual image, but V1 is also capable of encoding the

271 spatiotemporal aspects of a visual sequence (Gavornik and Bear, 2014; Sidorov et al., 2020;

272 Finnie et al., 2021). Like SRP, this learning causes the magnitude of visually evoked responses

273 recorded in V1 to potentiate over days. Unlike SRP, this learning does not require NMDA

274 receptors and can be prevented by antagonizing muscarinic acetylcholine receptors in V1

275 (Gavornik and Bear, 2014), and M2 receptors specifically (Sarkar et al., 2022). Given that

276 increasing estrogen levels have been shown to enhance signaling in cholinergic basal forebrain

277 neurons which project robustly to V1 (Gibbs, 1997; Towart et al., 2003), that estrogen can

278 modulate the expression and function of mAChRs (Cardoso et al., 2004; Pereira et al., 2008),

279 that M2 receptors have been implicated in estrogen-induced enhancement of hippocampal

280 memory (Daniel and Dohanich, 2001; Daniel et al., 2005), and that involvement of 7 $\alpha$-Estradiol

281 can modulate ocular dominance plasticity in rat V1 (Sengupta et al., 2019) we reasoned that this

282 form of learning might be more susceptible to sex differences than SRP.

$284(n=15)$ and male $(n=12)$ mice in response to 200 presentations of a sequence of four oriented

285 sinusoidal gratings (ABCD, where each letter represents a unique orientation; Figure 3D) for

286 five days. On the fifth day, both groups were shown the trained sequence and a novel sequence

287 constructed by reordering the same elements (DCBA). Sequence evoked potentials increased

288 with training in both male and female groups (Figure 3E) and were quantified by averaging the

289 peak-to-peak responses of elements B and C (which show the largest potentiation and are not

290 biased by the large response that occurs when a patterned stimulus follow the gray screen, as 
occurs in A and D) (Figure 2F). As in the SRP experiment, data was normalized by day 1 averages to isolate potentiation. As expected, the increase across days in this metric was highly significant $\left(F_{4,125}=16.88, p<0.001\right)$. While responses in female mice potentiated less than they

294 did in male mice (female: $\mathrm{M}=1.86, \mathrm{SD}=0.84$; male: $\mathrm{M}=2.10, \mathrm{SD}=1.07$ ) this was not a significant $295 \operatorname{effect}\left(F_{1,125}=3.09, p=0.08\right)$ and there was no significant interaction $\left(F_{4,125}=0.35, p=0.84\right)$. Unlike

296 in the SRP experiment, however, the interpretation of this data did change when statistics were 297 calculated using raw voltage measurements (Figure 2G). In this case potentiation over days 298 remained highly significant $\left(F_{4,125}=16.51, p<0.001\right)$, and there was also a highly significant 299 effect of $\operatorname{sex}\left(F_{1,125}=14.56, p<0.001\right)$, though still no significant interaction $\left(F_{4,125}=0.613\right.$

$300 p=0.65)$. The statistical effect of sex was large $\left(\eta_{\mathrm{p}}{ }^{2}=0.10\right.$, observed power $\left.=0.97\right)$ and resulted

301 from responses that were larger in male mice than females (female: $\mathrm{M}=279.24, \mathrm{SD}=125.45$;

302 male: $\mathrm{M}=364.98, \mathrm{SD}=187.28$ ). On day 5, the trained sequence $\mathrm{ABCD}$ drove larger responses

303 than did the novel sequence DCBA $\left(F_{1,50}=14.41 p<0.001\right)$ though with no effect of sex

$304\left(F_{1,50}=0.31, p=0.58\right)$ or interaction $\left(F_{1,50}=1.13, p=0.29\right)$.

Estrous stage effects experience dependent plasticity

There is extensive data showing that estrogen fluctuation impacts plasticity and learning

308 in the hippocampus (Maren et al., 1994; Li et al., 2004) and prefrontal cortex (Keenan et al.,

309 2001), but there is little data on how sensory cortices are influenced by gonadal hormones

310 (McEwen and Milner, 2017). We did not track or control for estrous cycle in the previous

311 plasticity experiments. Since cycling occurs irregularly, it is possible that any effects of estrous

312 phase on the induction or expression of plasticity averaged out across the population which could

313 explain why there was no significant difference between the sexes in the 5-day SRP experiment. 
314 To address this possibility, we implanted mice at approximately P56 (female mice reach sexual

315 maturity at approximately 8 weeks old) and began accumulating staging records after surgical

316 recovery. The experimental approach was to compare the evolution of plasticity in groups

317 starting at opposite ends of the estrous cycle, i.e. diestrus and estrus. To this end, female mice

318 that had completed at least one full estrous cycle were sorted into yoked groups and exposed to

319 the SRP induction protocol (Figure 4A). As before, normalized VEP magnitudes increased

320 significantly over days (Figure 4B-C, $\left.F_{4,115}=20.10 p<0.001\right)$ and there was no interaction term

$321\left(F_{4,115}=0.53, p=0.71\right)$, but VEPs in mice starting in diestrus potentiated $(n=12, \mathrm{M}=1.71$,

$322 \mathrm{SD}=0.0 .32$ on day 5$)$ significantly more $\left(F_{1,115}=5.404, p=0.02\right)$ than those starting in estrus

$323(n=13, \mathrm{M}=1.51, \mathrm{SD}=0.20)$ with a small effect size $\left(\eta_{\mathrm{p}}^{2}=0.05\right.$, observed power $\left.=0.64\right)$. On day

324 five, the response to the novel stimulus is significantly smaller than to the familiar $\left(F_{1,46}=2.67\right.$,

$325 p<0.001)$ with no significant effect of initial stage $\left(F_{1,46}=2.08, p=0.16\right)$ or interaction $\left(F_{1,46}=2.21\right.$,

$326 p<0.14)$. When the analysis is repeated using raw voltage values, the effect of the estrous cycle is

327 more pronounced. On day 1, VEPs from mice in diestrus $(\mathrm{M}=269.99, \mathrm{SD}=79.83)$ were smaller

328 than those starting in estrus $(M=336.60, S D=47.88)$ with highly significant effects of day

$329\left(F_{4,115}=21.99, p<0.001\right)$ and stage $\left(F_{1,115}=16.54, p<0.001\right)$, though still without a significant

330 interaction $\left(F_{4,115}=0.22, p=0.92\right)$. Comparing means between staging groups across days using

331 Bonferroni corrected t-tests revealed that the difference between estrus and diestrus was

332 significant on day $1(t(23)=2.05, p=0.04)$ and day $4(t(23)=2.50, p=0.01)$. There was no

333 significant difference between stage cohorts on any other day.

334 Though all mice were grouped by estrous cycle stage on the first day of SRP induction,

335 we found the cycling to be irregular with a high variability within each group across the 5 days

336 of measurements (Table 1) which made it difficult to determine the extent to which the 
difference in estrous cycling averaged out in later days, and might explain the significant result on day 4 but not on days 2,3 or 5 . In order to measure plasticity expression and induction within specific hormonal windows, we repeated the SRP experiment with a single day of exposure with testing occurring the following day (Figure 4E). Mice found to be in a different stage on day two

341 (test day) relative to day one were removed from the data set (3 out of 17 mice were excluded for

342 being in a different stage on day two, 2 diestrus animals entered estrus, 1 estrus mice entered

343 diestrus). Analyzing normalized data (Figure 4G), we see that there is highly significant

344 potentiation between days 1 and $2\left(F_{1,24}=19.26, p<0.001\right)$. Diestrus $(n=8)$ mice potentiate slightly

345 more than estrus $(n=6)$ mice after one day of SRP training $\left(F_{1,24}=0.02, p<0.001\right)$ though this is a

346 very small effect $\left(\eta_{\mathrm{p}}{ }^{2}=0.001\right.$, observed power $\left.=0.05\right)$. There is no significant interaction

$347\left(F_{1,24}=0.02, p=0.88\right)$. On day two, there is no significant effect of stage $\left(F_{1,24}=0.14, p=0.71\right)$ or

348 interaction between stage and stimulus $\left(F_{1,24}=0.01, p=0.94\right)$, but there is a significant difference

349 between VEPs evoked by the familiar and novel stims $\left(F_{1,24}=15.89, p=0.001\right)$. Analyzing raw

350 voltages (data not shown) shows the same pattern, though the significant effect of stage between

351 days 1 and 2 is noticeably larger $\left(F_{1,24}=5.56, p=0.03, \eta_{\mathrm{p}}{ }^{2}=0.18\right.$, observed power $\left.=0.62\right)$.

352 Comparing Bonferroni corrected t-tests show that the difference between estrus and diestrus is

353 significant only on day two (Day1: $\mathrm{t}(12)=1.21, \mathrm{p}=0.24$; Day $2: \mathrm{t}(12)=2.13, \mathrm{p}=0.04)$.

Having already found an effect of sequence between male and female mice, and owing to

355 the difficulty of conducting an estrus-controlled 5-day experiment, we used the same abbreviated

356 2-day training protocol for the sequence stimulus (Figure 4H). Even with this narrowed 24-hour

357 window, 7 out of 30 animals were excluded for being in a different stage on day 2 than day 1 (3

358 estrus animals entered metestrus, 2 diestrus entered proestrus, and 2 diestrus entered estrus).

359 Analyzing normalized data showed that sequence responses potentiated significantly after one 
360 day of training $\left(F_{1,42}=8.50, p=0.01\right)$, but surprisingly there was no significant difference

$361\left(F_{1,42}=0.004, p=0.95\right)$ between mice in estrus $(n=12)$ and diestrus $(n=11)$ nor was there a

362 significant interaction between stage and day $\left(F_{1,42}=0.004 p=0.95\right)$. While the response to the

363 novel sequence $(\mathrm{M}=1.26, \mathrm{SD}=0.53)$ was smaller on average than to the familiar sequence

$364(\mathrm{M}=1.47, \mathrm{SD}=0.54)$ after one day of training, this was not a significant effect $\left(F_{1,42}=1.75 p=0.19\right)$

365 and there was no effect of stage $\left(F_{1,42}=0.13 p=0.72\right)$ or interaction $\left(F_{1,42}=0.06, p=0.81\right)$.

366 Analyzing raw data produced the same result (Day: $F_{1,42}=8.02, p=0.01$; Stage: $F_{1,42}=0.41$,

$367 p=0.52$; Stage $*$ Day: $\left.F_{1,42}=0.03, p=0.86\right)$.

369 Discussion

370 Many studies have addressed visual acuity in males and females, and their findings of specific

371 physiological measures showing sexual dimorphism are often contradictory ((Brabyn and

372 Mcguinness, 1979; La Marche et al., 1986; Mitchell et al., 1987; Abramov et al., 2012); but see

373 also the lack of sex differences in (Ishigaki and Miyao, 1994)). There is a trend towards males

374 having better acuity at high spatial frequencies (Burg, 1966; McGuinness, 1976) and females

375 having larger amplitude VEPs overall (La Marche et al., 1986; Fein and Brown, 1987; Sharma et

376 al., 2015). Rat data mirrors human findings in that female animals show larger VEPs (Dyer and

377 Swartzwelder, 1978), but this effect is limited to low spatial frequencies (Seymoure and Juraska,

378 1997). Further, estrogen signaling has been reported to modulate several forms of visual

379 recognition and memory in females (Penton-Voak et al., 1999; Resnick and Maki, 2001;

380 Mazzocco et al., 2006). Our data does not reveal any statistically significant differences in visual

381 responsiveness between male and female mice at either high or low spatial frequencies. We did

382 see a trend towards female mice having larger VEPs in response to low spatial frequencies 
383 (Figure 1A, 0.05 cycles/degree) in our first experiment, but in our SRP experiment VEPs in

384 female mice started smaller than in males (Figure 2B, black line) and the relative magnitude of

385 estrus/diestrus groups differed in our two staged SRP experiments (Figure 4B,F). These intra-

386 cohort differences, which are fairly common, were within the standard errors of the data and

387 underscore the importance of yoked treatment groups throughout the course of plasticity

388 experiments.

Overall, our SRP findings suggest that sex and estrous cycle has only a small to modest

390 effect on spatial learning requiring NMDARs. Our results show that sex and estrous cycle clearly

391 affect sequence learning, however, which is not surprising given what we know about the

392 mechanistic basis of this plasticity. Visual sequence learning requires muscarinic acetylcholine

393 signaling (Gavornik and Bear, 2014; Sarkar et al., 2022), and there is abundant literature

394 revealing that estrogen modulates cholinergic activity in the rat brain: choline acetyltransferase

395 (ChAT) mRNA levels fluctuate across the estrous cycle (Gibbs, 1996, 1998) and estrogen

396 administration increases ChAT mRNA (Luine and Hearns, 1990), ChAT protein expression

397 (Gibbs, 1997), acetylcholine release (Gibbs et al., 1997; Gabor et al., 2003), and choline reuptake

398 at the synapse (O'Malley et al., 1987; Singh et al., 1994). Furthermore, estrogen attenuates the

399 effects of scopolamine in passive avoidance, demonstrating functional muscarinic cholinergic

400 receptors are required for a different across-day learning task (Gibbs, 1998). This divergence

401 between passive avoidance and visual sequence learning data may be attributable to differences

402 in the impact of gonadal hormones on the hippocampus (which is required for passive avoidance

403 (Best and Orr, 1973)) and primary sensory cortex.

The hippocampus is one of the brain regions most dramatically influenced by the

405 presence or absence of estrogen (Spencer et al., 2008) and its presence is required for sequence 
potentiation (Finnie et al., 2021), though the nature of this relationship is still under investigation. Sexual dimorphism has also been reported in the amygdala (Blume et al., 2017) and the prefrontal cortex (Duclot and Kabbaj, 2015; Evans and Hampson, 2015) and our results suggest potentially interesting parallels between sexual dimorphism in limbic system plasticity when compared to sensoricortical plasticity. This work also describes relatively simple plasticity

411 assays in V1 that can potentially be used to probe the relation between sex hormones and 412 functional plasticity in vivo. How do our findings in the primary visual cortex relate to other cortical regions? It has 414 been long recognized that cortical circuits are organized around a common architecture, leading

415 to the hypothesis that all areas of the cortex implement a common set of algorithms (Creutzfeldt, 416 1977) (Mountcastle, 1978) and the notion that visual circuits can be understood as a proxy for 417 the rest of the cortex (Douglas and Martin, 1991). Shared computational mechanisms support 418 both short and long term memory in various cortical regions (Himberger et al., 2018). These 419 observations imply that our findings in V1 will be relevant in other cortical areas. However, 420 there is currently a lack of studies addressing sexual dimorphism in different sensory modalities 421 and it's possible there are interesting areas of divergence. For example, an individual study in S1 422 has shown that nitric oxide signaling is necessary for male - but not female - whisker 423 deprivation plasticity (Dachtler et al., 2012) suggesting that more complex experiments may 424 reveal functionally relevant sex differences not yet explored in V1.

425 We assumed that our female mice would have 4-5 day cycles based on oft-stated rules for 426 mice (Byers et al., 2012; Prendergast et al., 2014) and designed our SRP experimental timeline 427 around this window (Figure 4A). However, our staging data (Table 1) illustrates that description 428 of an estrogen "cycle", with its implicit suggestion of predictable regularity, is something of a 
429 misnomer in lab mice. Cycling in our mice was both longer (6-12 days on average) and more

430 unpredictable than we expected. For this reason, we amended our recording timeline to eliminate

431 as much variability as possible when recording staged Sequence Learning and limited our

432 protocol to 24 hours (Figure 4H).

433 Several factors might explain this variability. First, exposure to male mice increases

434 cycle regularity and decreases length (Whitten, 1956). This "Whitten effect", however, occurs

435 only through nearly direct contact with male urine or dirty bedding, and washing equipment

436 between male and female mice is sufficient to avoid this confound. A second factor is age. A

437 longitudinal study of lifetime estrous cycling (Nelson et al., 1982) detected regular 4-5 day

438 cycles from 4 to 12 months of age, but cycles greater than 6 days were common for animals of 2-

4394 months (which includes our mice). The ability to combine housing of non-littermate females

440 and reduce housing costs is a major advantage to including female mice, though this can effect

441 estrous cycle length: individually housed females have 4-5 day regular cycles (Lamond, 1959)

442 (Byers et al., 2012), 3-5 group-housed females have $\sim 8$ day cycles with a distribution spread

443 from 4 to 14 days (Champlin, 1971), and 20 group-housed females often cease cycling altogether

444 (Champlin, 1971; Ryan and Schwartz, 1977).

445 Female mice have been excluded from experiments, in part, due to concern that daily

446 staging would be necessary to track estrus. Fortunately, our findings suggest that the effects of

447 this variability can probably be ameliorated through simple in-group normalization of male and

448 female mice. The practical difficulties designing multi-day yoked experiments are non-trivial and

449 should be carefully considered for any studies where estrous cycle is found to play a significant

450 role on measured outcomes. While these considerations are known to experts in the field, our

451 own experience and conversations with colleagues whose primary focus is not endocrinology 
452 suggest that many research labs underestimate the challenges associated with planning and 453 executing experiments that track estrous cycle. Speaking to this group specifically: we found

454 the methodology of (Dey et al., 2015) for daily staging referenced against the estrous cycle

455 wheel graphic in Figure 1 of (Byers et al., 2012) to be effective. The process is fast (10 animals

456 can be done in 15 minutes) and simple. The animals seemed unbothered by the process, and we

457 noted neither signs of discomfort (e.g. squeaking) nor aggression (e.g., biting) during vaginal

458 lavage. Other papers in the literature use various histological stains which require fixation or

459 prolonged drying times (Cora et al., 2015) (McLean et al., 2012), but unstained leukocytes

460 (Figure2 black circles) and cornified epithelial cells (Figure 2 white boxes) are unambiguous,

461 and nucleated epithelial cells (Figure 2 black boxes) are easily identifiable (for more unstained

462 example images, see (Caligioni, 2009) and (Goldman et al., 2007)).

There are valid arguments for including both sexes in order to generate more complete

464 database of primary research for use in developing medical treatments (Koss and Frick, 2017)

465 and from those who plan to continue with male-only experiments (Eliot and Richardson, 2016).

466 While our data could potentially be used to support either position, by showing an effect of sex it

467 clearly suggests limits on the general applicability of conclusions based on plasticity experiments

468 which exclude female mice or subject them to gonadectomies. There is also practical value in

469 including both sexes related to animal resource utilization, potentially reducing cost and waste.

470 Overall, we think the minimal additional effort required to control for the additional variability

471 associated with mixed-sex cohorts is worth in most V1 plasticity experiments, particularly given

472 the NIH imperative to include sex as a biological variable. 


\section{Author Contributions}

R.W.S. and J.P.G designed all experiments. R.W.S. C.J. and J.P.G. analyzed data and wrote the

manuscript. R.W.S. and C.J. conducted all experiments.

\section{Funding}

480 This work was funded by NIMH R00MH099654 and using lab startup funds provided by the

481 Boston University Biology Department.

\section{References}

Abramov I, Gordon J, Feldman O, Chavarga A (2012) Sex \& vision I: Spatio-temporal resolution. Biol Sex Differ 3:20.

Becker JB, Prendergast BJ, Liang JW (2016) Female rats are not more variable than male rats: a meta-analysis of neuroscience studies. Biol Sex Differ 7:34.

Beery AK, Zucker I (2011) Sex bias in neuroscience and biomedical research. Neurosci Biobehav Rev 35:565-572.

Best PJ, Orr J, Jr. (1973) Effects of hippocampal lesions on passive avoidance and taste aversion conditioning. Physiol Behav 10:193-196.

Blume SR, Freedberg M, Vantrease JE, Chan R, Padival M, Record MJ, DeJoseph MR, Urban JH, Rosenkranz JA (2017) Sex- and Estrus-Dependent Differences in Rat Basolateral Amygdala. J Neurosci 37:10567-10586.

Brabyn LB, Mcguinness D (1979) Gender Differences in Response to Spatial-Frequency and Stimulus Orientation. Percept Psychophys 26:319-324.

Burg A (1966) Visual acuity as measured by dynamic and static tests: a comparative evaluation. J Appl Psychol 50:460-466.

Byers SL, Wiles MV, Dunn SL, Taft RA (2012) Mouse estrous cycle identification tool and images. PLoS One 7:e35538.

\section{Caligioni CS (2009) Assessing reproductive status/stages in mice. Curr Protoc Neurosci} Appendix 4:Appendix 4I.

Cardoso CC, Pereira RT, Koyama CA, Porto CS, Abdalla FM (2004) Effects of estrogen on muscarinic acetylcholine receptors in the rat hippocampus. Neuroendocrinology 80:379-386.

Champlin AK (1971) Suppression of oestrus in grouped mice: the effects of various densities and the possible nature of the stimulus. J Reprod Fertil 27:233-241.

Chen JR, Yan YT, Wang TJ, Chen LJ, Wang YJ, Tseng GF (2009) Gonadal hormones modulate the dendritic spine densities of primary cortical pyramidal neurons in adult female rat. Cereb

Cortex 19:2719-2727.

510 Clayton JA, Collins FS (2014) Policy: NIH to balance sex in cell and animal studies. Nature $511 \quad 509: 282-283$. 
Cooke SF, Bear MF (2010) Visual experience induces long-term potentiation in the primary visual cortex. J Neurosci 30:16304-16313.

Cooke SF, Bear MF (2012) Stimulus-selective response plasticity in the visual cortex: an assay for the assessment of pathophysiology and treatment of cognitive impairment associated with psychiatric disorders. Biol Psychiatry 71:487-495.

Cooke SF, Komorowski RW, Kaplan ES, Gavornik JP, Bear MF (2015) Visual recognition memory, manifested as long-term habituation, requires synaptic plasticity in V1. Nat Neurosci 18:262-271.

Cora MC, Kooistra L, Travlos G (2015) Vaginal Cytology of the Laboratory Rat and Mouse: Review and Criteria for the Staging of the Estrous Cycle Using Stained Vaginal Smears. Toxicol Pathol 43:776-793.

Creutzfeldt OD (1977) Generality of the functional structure of the neocortex. Naturwissenschaften 64:507-517.

Cyr M, Ghribi O, Thibault C, Morissette M, Landry M, Di Paolo T (2001) Ovarian steroids and selective estrogen receptor modulators activity on rat brain NMDA and AMPA receptors. Brain Res Brain Res Rev 37:153-161.

Dachtler J, Hardingham NR, Fox K (2012) The role of nitric oxide synthase in cortical plasticity is sex specific. J Neurosci 32:14994-14999.

Daniel JM, Dohanich GP (2001) Acetylcholine mediates the estrogen-induced increase in NMDA receptor binding in CA1 of the hippocampus and the associated improvement in working memory. J Neurosci 21:6949-6956.

Daniel JM, Hulst JL, Lee CD (2005) Role of hippocampal M2 muscarinic receptors in the estrogen-induced enhancement of working memory. Neuroscience 132:57-64.

Dey S, Chamero P, Pru JK, Chien MS, Ibarra-Soria X, Spencer KR, Logan DW, Matsunami H, Peluso JJ, Stowers L (2015) Cyclic Regulation of Sensory Perception by a Female Hormone Alters Behavior. Cell 161:1334-1344.

Douglas RJ, Martin KA (1991) A functional microcircuit for cat visual cortex. J Physiol 440:735-769.

Duclot F, Kabbaj M (2015) The estrous cycle surpasses sex differences in regulating the transcriptome in the rat medial prefrontal cortex and reveals an underlying role of early growth response 1. Genome Biol 16:256.

Dyer RS, Swartzwelder HS (1978) Sex and strain differences in the visual evoked potentials of albino and hooded rats. Pharmacol Biochem Behav 9:301-306.

Eliot L, Richardson SS (2016) Sex in Context: Limitations of Animal Studies for Addressing Human Sex/Gender Neurobehavioral Health Disparities. J Neurosci 36:11823-11830.

Evans KL, Hampson E (2015) Sex differences on prefrontally-dependent cognitive tasks. Brain Cogn 93:42-53.

Fein G, Brown FF (1987) Gender differences in pattern reversal evoked potentials in normal elderly. Psychophysiology 24:683-690.

Fields RD (2014) NIH policy: mandate goes too far. Nature 510:340.

Finnie PSB, Komorowski RW, Bear MF (2021) The spatiotemporal organization of experience dictates hippocampal involvement in primary visual cortical plasticity. Curr Biol 31:39964008 e3996.

Frenkel MY, Sawtell NB, Diogo AC, Yoon B, Neve RL, Bear MF (2006) Instructive effect of visual experience in mouse visual cortex. Neuron 51:339-349. 
Fritz AK, Amrein I, Wolfer DP (2017) Similar reliability and equivalent performance of female and male mice in the open field and water-maze place navigation task. Am J Med Genet C Semin Med Genet 175:380-391.

Gabor R, Nagle R, Johnson DA, Gibbs RB (2003) Estrogen enhances potassium-stimulated acetylcholine release in the rat hippocampus. Brain Res 962:244-247.

Gao M, Whitt JL, Huang S, Lee A, Mihalas S, Kirkwood A, Lee HK (2017) Experiencedependent homeostasis of 'noise' at inhibitory synapses preserves information coding in adult visual cortex. Philosophical transactions of the Royal Society of London Series B, Biological sciences 372.

Gavornik JP, Bear MF (2014) Learned spatiotemporal sequence recognition and prediction in primary visual cortex. Nat Neurosci 17:732-737.

Gazzaley AH, Weiland NG, McEwen BS, Morrison JH (1996) Differential regulation of NMDAR1 mRNA and protein by estradiol in the rat hippocampus. J Neurosci 16:6830-6838.

Gibbs RB (1996) Fluctuations in relative levels of choline acetyltransferase mRNA in different regions of the rat basal forebrain across the estrous cycle: effects of estrogen and progesterone. J Neurosci 16:1049-1055.

Gibbs RB (1997) Effects of estrogen on basal forebrain cholinergic neurons vary as a function of dose and duration of treatment. Brain Res 757:10-16.

Gibbs RB (1998) Levels of trkA and BDNF mRNA, but not NGF mRNA, fluctuate across the estrous cycle and increase in response to acute hormone replacement. Brain Res 810:294.

Gibbs RB, Hashash A, Johnson DA (1997) Effects of estrogen on potassium-stimulated acetylcholine release in the hippocampus and overlying cortex of adult rats. Brain Res 749:143-146.

Goldman JM, Murr AS, Cooper RL (2007) The rodent estrous cycle: characterization of vaginal cytology and its utility in toxicological studies. Birth Defects Res B Dev Reprod Toxicol 80:84-97.

Gould E, Woolley CS, Frankfurt M, McEwen BS (1990) Gonadal steroids regulate dendritic spine density in hippocampal pyramidal cells in adulthood. J Neurosci 10:1286-1291.

Himberger KD, Chien HY, Honey CJ (2018) Principles of Temporal Processing Across the Cortical Hierarchy. Neuroscience.

Huang S, Huganir RL, Kirkwood A (2013) Adrenergic gating of Hebbian spike-timingdependent plasticity in cortical interneurons. J Neurosci 33:13171-13178.

Huang S, Trevino M, He K, Ardiles A, Pasquale R, Guo Y, Palacios A, Huganir R, Kirkwood A (2012) Pull-push neuromodulation of LTP and LTD enables bidirectional experience-induced synaptic scaling in visual cortex. Neuron 73:497-510.

Huang ZJ, Kirkwood A, Pizzorusso T, Porciatti V, Morales B, Bear MF, Maffei L, Tonegawa S (1999) BDNF regulates the maturation of inhibition and the critical period of plasticity in mouse visual cortex. Cell 98:739-755.

Ishigaki H, Miyao M (1994) Implications for dynamic visual acuity with changes in aged and sex. Percept Mot Skills 78:363-369.

Jazin E, Cahill L (2010) Sex differences in molecular neuroscience: from fruit flies to humans. Nature reviews Neuroscience 11:9-17.

Jeong JK, Tremere LA, Burrows K, Majewska AK, Pinaud R (2011) The mouse primary visual cortex is a site of production and sensitivity to estrogens. PLoS One 6:e20400. 
Kaplan ES, Cooke SF, Komorowski RW, Chubykin AA, Thomazeau A, Khibnik LA, Gavornik JP, Bear MF (2016) Contrasting roles for parvalbumin-expressing inhibitory neurons in two forms of adult visual cortical plasticity. Elife 5.

Keenan PA, Ezzat WH, Ginsburg K, Moore GJ (2001) Prefrontal cortex as the site of estrogen's effect on cognition. Psychoneuroendocrinology 26:577-590.

Koss WA, Frick KM (2017) Sex differences in hippocampal function. J Neurosci Res 95:539562.

La Marche JA, Dobson WR, Cohn NB, Dustman RE (1986) Amplitudes of visually evoked potentials to patterned stimuli: age and sex comparisons. Electroencephalogr Clin Neurophysiol 65:81-85.

Lamond DR (1959) Effect of stimulation derived from other animals of the same species on oestrous cycles in mice. J Endocrinol 18:343-349.

Li C, Brake WG, Romeo RD, Dunlop JC, Gordon M, Buzescu R, Magarinos AM, Allen PB, Greengard P, Luine V, McEwen BS (2004) Estrogen alters hippocampal dendritic spine shape and enhances synaptic protein immunoreactivity and spatial memory in female mice. Proc Natl Acad Sci U S A 101:2185-2190.

Luine V, Hearns M (1990) Spatial Memory Deficits in Aged Rats - Contributions of the Cholinergic System Assessed by Chat. Brain Research 523:321-324.

Maren S, De Oca B, Fanselow MS (1994) Sex differences in hippocampal long-term potentiation (LTP) and Pavlovian fear conditioning in rats: positive correlation between LTP and contextual learning. Brain Res 661:25-34.

Mazzocco MM, Singh Bhatia N, Lesniak-Karpiak K (2006) Visuospatial skills and their association with math performance in girls with fragile $\mathrm{X}$ or Turner syndrome. Child Neuropsychol 12:87-110.

McCarthy MM, Arnold AP, Ball GF, Blaustein JD, De Vries GJ (2012) Sex differences in the brain: the not so inconvenient truth. J Neurosci 32:2241-2247.

McEwen BS, Milner TA (2017) Understanding the broad influence of sex hormones and sex differences in the brain. J Neurosci Res 95:24-39.

McGuinness D (1976) Away from a unisex psychology: individual differences in visual sensory and perceptual processes. Perception 5:279-294.

McLean AC, Valenzuela N, Fai S, Bennett SA (2012) Performing vaginal lavage, crystal violet staining, and vaginal cytological evaluation for mouse estrous cycle staging identification. $\mathrm{J}$ Vis Exp:e4389.

Mitchell KW, Howe JW, Spencer SR (1987) Visual evoked potentials in the older population: age and gender effects. Clin Phys Physiol Meas 8:317-324.

Mogil JS, Chanda ML (2005) The case for the inclusion of female subjects in basic science studies of pain. Pain 117:1-5.

Mountcastle VB (1978) Brain mechanisms for directed attention. J R Soc Med 71:14-28.

Nelson JF, Felicio LS, Randall PK, Sims C, Finch CE (1982) A longitudinal study of estrous cyclicity in aging C57BL/6J mice: I. Cycle frequency, length and vaginal cytology. Biol Reprod 27:327-339.

O'Malley CA, Hautamaki RD, Kelley M, Meyer EM (1987) Effects of ovariectomy and estradiol benzoate on high affinity choline uptake, ACh synthesis, and release from rat cerebral cortical synaptosomes. Brain Res 403:389-392.

Penton-Voak IS, Perrett DI, Castles DL, Kobayashi T, Burt DM, Murray LK, Minamisawa R (1999) Menstrual cycle alters face preference. Nature 399:741-742. 
Pereira RT, Porto CS, Godinho RO, Abdalla FM (2008) Effects of estrogen on intracellular signaling pathways linked to activation of muscarinic acetylcholine receptors and on acetylcholinesterase activity in rat hippocampus. Biochem Pharmacol 75:1827-1834.

Phillips SM, Sherwin BB (1992) Variations in memory function and sex steroid hormones across the menstrual cycle. Psychoneuroendocrinology 17:497-506.

Porciatti V, Pizzorusso T, Maffei L (1999) The visual physiology of the wild type mouse determined with pattern VEPs. Vision Res 39:3071-3081.

Prendergast BJ, Onishi KG, Zucker I (2014) Female mice liberated for inclusion in neuroscience and biomedical research. Neurosci Biobehav Rev 40:1-5.

Prusky GT, Douglas RM (2003) Developmental plasticity of mouse visual acuity. Eur J Neurosci 17:167-173.

Resnick SM, Maki PM (2001) Effects of hormone replacement therapy on cognitive and brain aging. Ann N Y Acad Sci 949:203-214.

Richardson SS, Reiches M, Shattuck-Heidorn H, LaBonte ML, Consoli T (2015) Opinion: Focus on preclinical sex differences will not address women's and men's health disparities.

Proceedings of the National Academy of Sciences 112:13419-13420.

Ryan KD, Schwartz NB (1977) Grouped female mice: demonstration of pseudopregnancy. Biol Reprod 17:578-583.

Sarkar S, Reyes CM, Jensen CM, Gavornik JP (2022) M2 receptors are required for spatiotemporal sequence learning in mouse primary visual cortex. bioRxiv:2022.2002.2009.479792.

Sawtell NB, Frenkel MY, Philpot BD, Nakazawa K, Tonegawa S, Bear MF (2003) NMDA receptor-dependent ocular dominance plasticity in adult visual cortex. Neuron 38:977-985.

Scharfman HE, Mercurio TC, Goodman JH, Wilson MA, MacLusky NJ (2003) Hippocampal excitability increases during the estrous cycle in the rat: a potential role for brain-derived neurotrophic factor. J Neurosci 23:11641-11652.

Sengupta DC, Lantz CL, Rumi MAK, Quinlan EM (2019) 17alpha Estradiol promotes plasticity of spared inputs in the adult amblyopic visual cortex. Sci Rep 9:19040.

Seymoure P, Juraska JM (1997) Vernier and grating acuity in adult hooded rats: the influence of sex. Behav Neurosci 111:792-800.

Shansky RM, Woolley CS (2016) Considering Sex as a Biological Variable Will Be Valuable for Neuroscience Research. J Neurosci 36:11817-11822.

Sharma R, Joshi S, Singh KD, Kumar A (2015) Visual Evoked Potentials: Normative Values and Gender Differences. J Clin Diagn Res 9:CC12-15.

Sidorov MS, Kim H, Rougie M, Williams B, Siegel JJ, Gavornik JP, Philpot BD (2020) Visual Sequences Drive Experience-Dependent Plasticity in Mouse Anterior Cingulate Cortex. Cell Rep 32:108152.

Singh M, Meyer EM, Millard WJ, Simpkins JW (1994) Ovarian steroid deprivation results in a reversible learning impairment and compromised cholinergic function in female SpragueDawley rats. Brain Res 644:305-312.

Spencer JL, Waters EM, Romeo RD, Wood GE, Milner TA, McEwen BS (2008) Uncovering the mechanisms of estrogen effects on hippocampal function. Front Neuroendocrinol 29:219-237.

Towart LA, Alves SE, Znamensky V, Hayashi S, McEwen BS, Milner TA (2003) Subcellular relationships between cholinergic terminals and estrogen receptor-alpha in the dorsal hippocampus. J Comp Neurol 463:390-401. 
bioRxiv preprint doi: https://doi.org/10.1101/2022.03.05.483062; this version posted March 7, 2022. The copyright holder for this preprint (which was not certified by peer review) is the author/funder, who has granted bioRxiv a license to display the preprint in perpetuity. It is made available under aCC-BY-NC-ND 4.0 International license.

692 Warren SG, Humphreys AG, Juraska JM, Greenough WT (1995) LTP varies across the estrous

693 cycle: enhanced synaptic plasticity in proestrus rats. Brain Res 703:26-30.

694 Whitten WK (1956) Modification of the oestrous cycle of the mouse by external stimuli

695 associated with the male. J Endocrinol 13:399-404.

696 Woolley CS, McEwen BS (1992) Estradiol mediates fluctuation in hippocampal synapse density

697 during the estrous cycle in the adult rat. J Neurosci 12:2549-2554.

698 
A.

B.

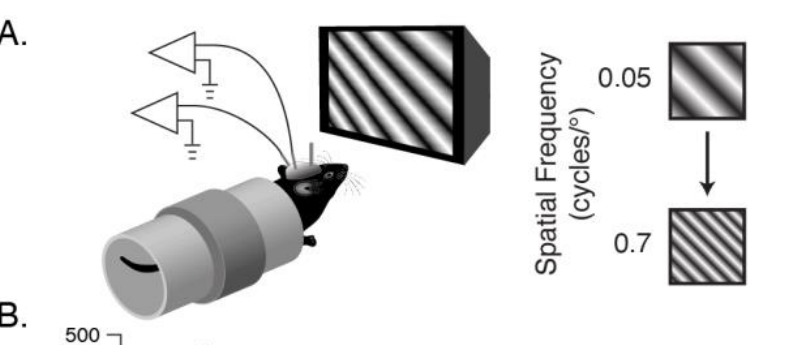

C.
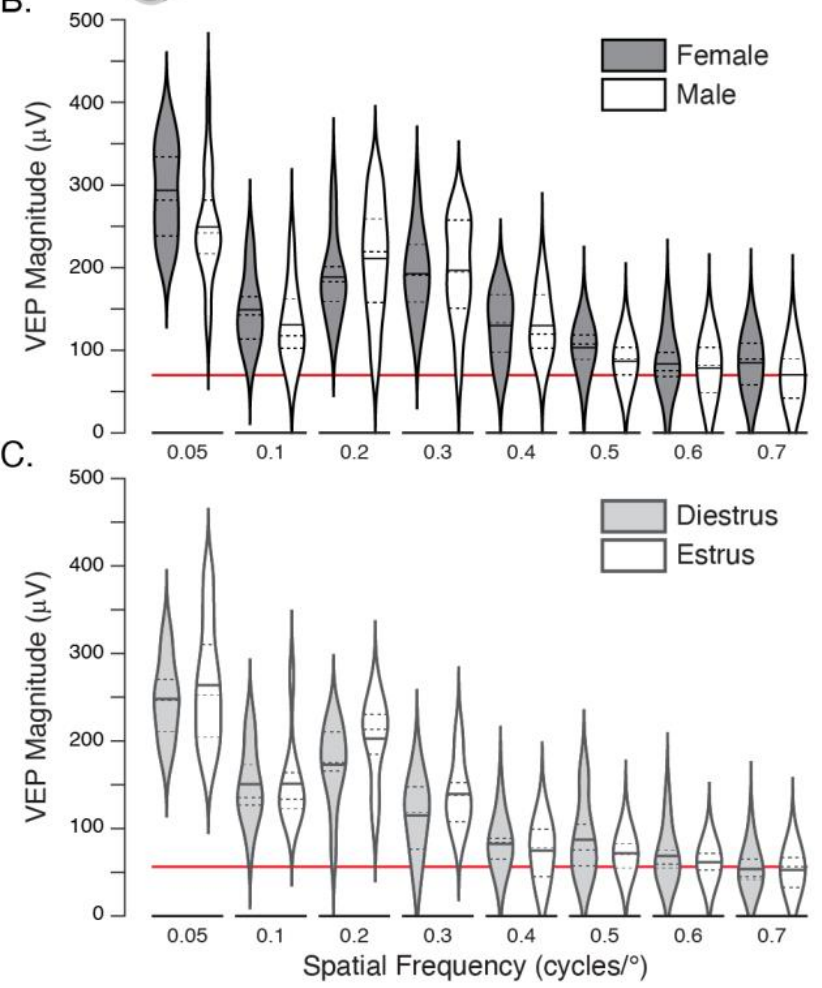

700 Figure 1: Visual acuity as measured by VEPs is comparable in female and male mice

701 A. Local field potentials are recorded from head-fixed mice (left) while they view phase-

702 reversing sinusoidal gratings with spatial frequencies varying from 0.05-0.7 (right). B. Violin

703 plots (dashed lines mark quartile boundaries and solid horizontal lines show the mean) showing

704 the peak-to-peak magnitude of VEPs recorded in female (shaded) and male (white) mice as a

705 function of spatial frequency. The red line marks the approximate noise-level recorded absent

706 visual stimulation. C. The same as in B, but for female mice in either estrus (shaded) or diestrus

707 (white). There is no effect of either sex or stage (see main text for statistical reporting). 
A.

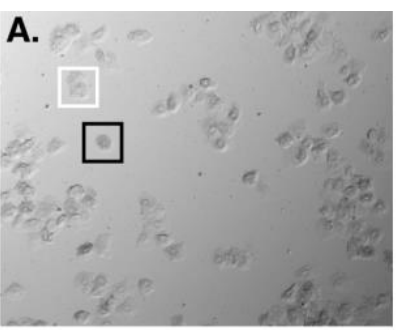

C.

\section{Figure 2: Example images of estrous stages from unstained vaginal cytology}

711 rounded with visible nucleus (black boxes). Cornified epithelium, flat, irregularly shaped with

712 no visible nucleus (white boxes). Leukocytes, small and spherical (black circles). A. Proestrus,

713 majority nucleated epithelium. B. Estrus, majority cornified epithelium. C. Metestrus, mix of

714 cornified epithelium, nucleated epithelium, and leukocytes. D. Diestrus, majority leukocytes. 
A.

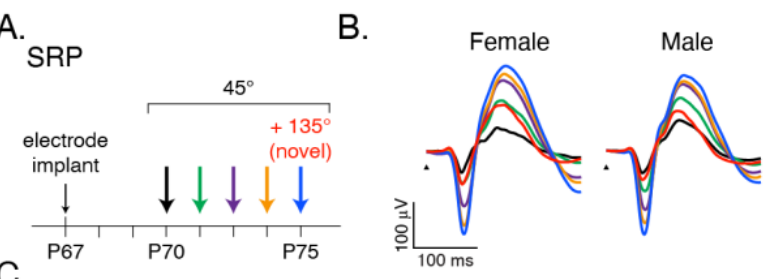

C.

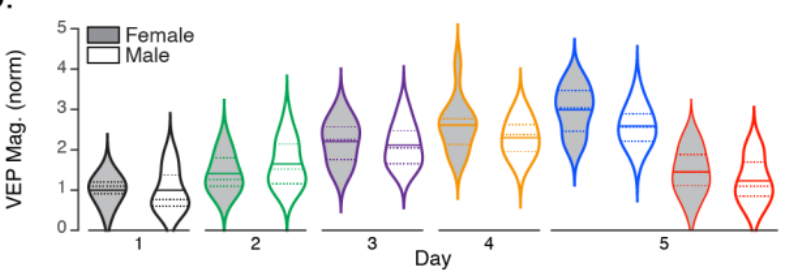

D.

E.

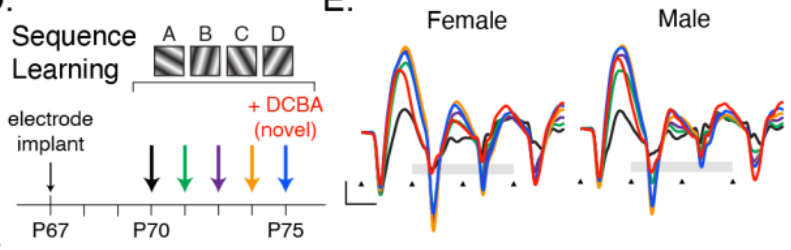

F.

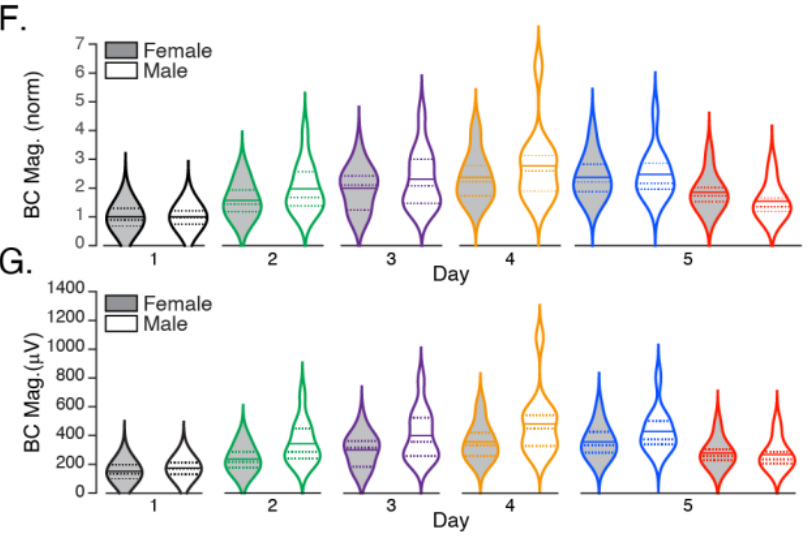

716 Figure 3: Experience dependent cortical plasticity is affected by sex

717 A. SRP experiment protocol. Animals were trained with repeated presentation of a $45^{\circ}$ stimulus

718 over five days. On the $5^{\text {th }}$ day, a novel stimulus (red, $135^{\circ}$ ) was interleaved with the familiar

719 stimulus (blue). B. Average VEP traces during SRP induction and expression in female and male

720 mice, color coded by day as in A. C. Violin plots showing the distribution of VEP magnitudes,

721 normalized to group averages on day 1, of female (shaded) and male (white) mice as a function

722 of experimental day. D. In Sequence Learning experiments, mice were shown 200 presentations

723 of the sequence ABCD every day for five days. On the fifth day, a novel sequence DCBA (red)

724 was interleaved with ABCD (blue). E. Group averaged sequence responses during sequence 
bioRxiv preprint doi: https://doi.org/10.1101/2022 03.05.483062; this version posted March 7, 2022. The copyright holder for this preprint (which was not certified by peer review) is the author/funder, who has granted bioRxiv a license to display the preprint in perpetuity. It is made available under aCC-BY-NC-ND 4.0 International license.

725 learning (black triangles indicate sequence element onset times, the scale bar is $100 \mu \mathrm{V}$ by 100

$726 \mathrm{~ms}$, color code as in D). Average quantified responses to elements B and C (indicated by the gray

727 bars in E) of female (shaded) and male (white) animals normalized to day 1 group averages, $\mathbf{F}$.

728 and raw voltages, G. See main text for statistical reporting.

729 
A.

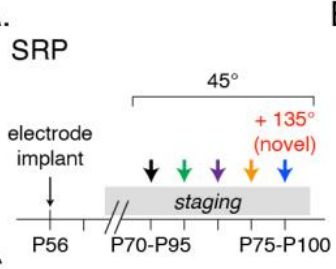

C.

ह

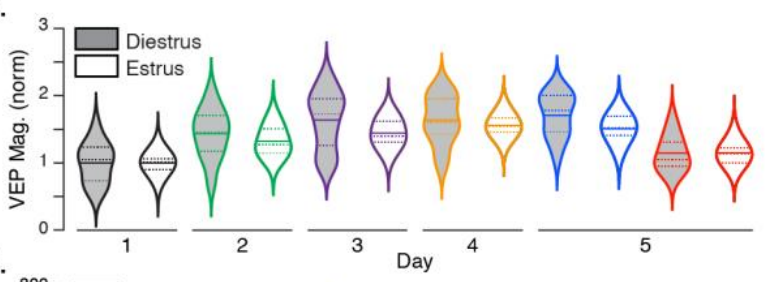

D.

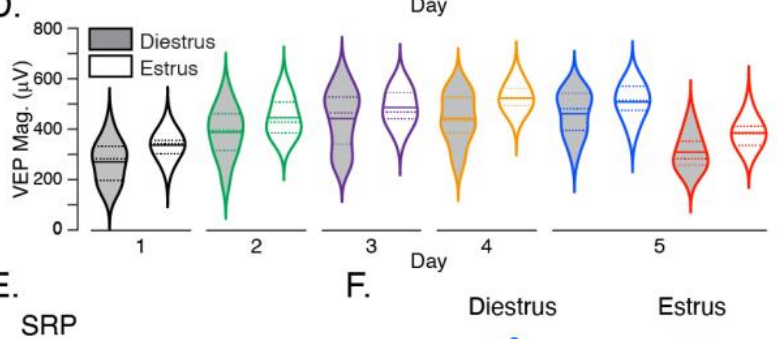

SRP

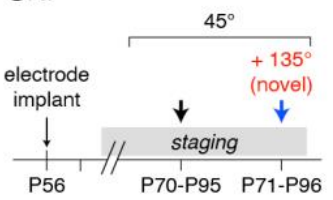

$\mathrm{H}$.

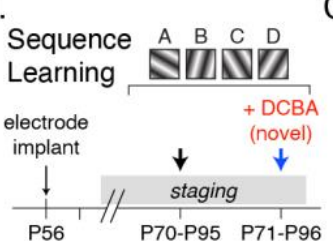

I. Diestrus

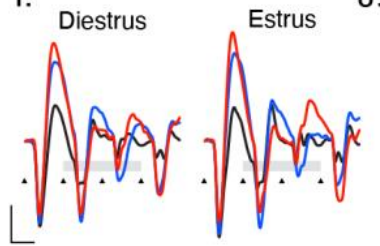

B.

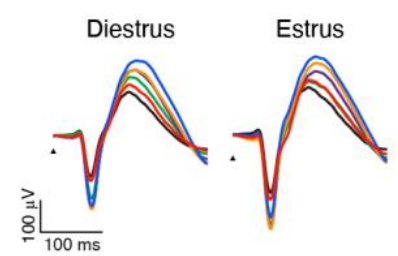

Diestrus Estrus

G.

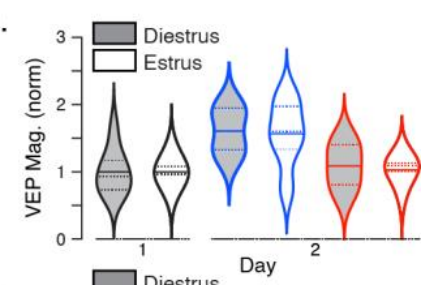

J.

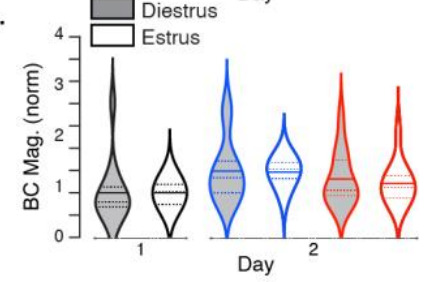

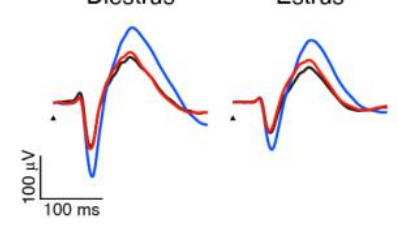

$731 \quad$ Figure 4: Experience dependent cortical plasticity is effected by estrous stage.

732 A. Five-day SRP experiments were conducted with animals grouped by estrous cycle stage on

733 day 1. B. Average traces over SRP induction and expression. Normalized, C., and raw, D., VEP

734 magnitudes for mice in diestrus (gray) and estrus (white) stage on day 1. E. Two-day SRP

735 experiments were conducted in animals that were in the same estrus stage on both days 1 and 2.

736 F. Average VEPs and G. normalized quantifications or animals in diestrus or estrus during 
bioRxiv preprint doi: https://doi.org/10.1101/2022.03.05.483062; this version posted March 7, 2022. The copyright holder for this preprint (which was not certified by peer review) is the author/funder, who has granted bioRxiv a license to display the preprint in perpetuity. It is made available under aCC-BY-NC-ND 4.0 International license.

737 induction and expression. H-J. Two-day sequence learning experiment, average VEPs, and 738 quantification as in E-G. 
bioRxiv preprint doi: https://doi.org/10.1101/2022.03.05.483062; this version posted March 7, 2022. The copyright holder for this preprint (which was not certified by peer review) is the author/funder, who has granted bioRxiv a license to display the preprint in perpetuity. It is made available under aCC-BY-NC-ND 4.0 International license.

\begin{tabular}{|c|c|c|c|c|c|c|c|c|c|c|c|c|c|c|c|c|c|c|c|c|c|c|c|c|c|c|c|c|c|c|}
\hline \multirow[b]{2}{*}{ mouse } & \multicolumn{26}{|c|}{ Days } & \multicolumn{4}{|c|}{ Totals } \\
\hline & 1 & 2 & 3 & 4 & 5 & \begin{tabular}{|l}
6 \\
6
\end{tabular} & 7 & & 8 & 9 & 10 & $\mid 11$ & 12 & 13 & 14 & 15 & 16 & 17 & 18 & 19 & 20 & 21 & 222 & 232 & & 25 & $\mathbf{P}$ & $\mathrm{E}$ & $\mathrm{M}$ & D \\
\hline 1 & $\mathrm{E}$ & $E$ & $\mathrm{M}$ & $\mathrm{D}$ & $\bar{D}$ & $\mathrm{D}$ & 1 & & $\mathrm{D}$ & $P$ & $P$ & D & D & $\mathrm{D}$ & $\mathrm{D}$ & $\mathrm{D}$ & $P$ & $\mathrm{E}$ & $\mathrm{E}$ & $\mathrm{E}$ & $\mathrm{E}$ & D & $\mathrm{D}$ & $\bar{D}$ & & $\bar{P}$ & 5 & 6 & 1 & 13 \\
\hline 2 & M & M & D & $\mathbf{P}$ & E & D & I & & & D & $\mathbf{E}$ & $E$ & M & $\mathbf{E}$ & D & D & D & $\mathbf{E}$ & $\mathbf{E}$ & $\mathbf{E}$ & $\mathrm{M}$ & D & D & P & & & & 9 & & 10 \\
\hline 3 & $\mathrm{E}$ & M & D & D & D & $\mathbf{P}$ & P & & $\mathbf{E}$ & E & $\mathbf{E}$ & E & $\mathbf{E}$ & $\mathrm{D}$ & D & D & D & $\mathbf{P}$ & M & $\mathrm{M}$ & $\mathrm{D}$ & D & D & P & E $N$ & M & 4 & 7 & 4 & 10 \\
\hline 4 & D & D & D & D & D & D & L & & D & D & $\mathbf{P}$ & $\mathbf{P}$ & D & $\mathrm{D}$ & D & $\mathrm{D}$ & D & $\mathrm{D}$ & D & $\mathrm{D}$ & $\mathrm{D}$ & D & D & D I & D I & D & $\therefore$ & 0 & 0 & 23 \\
\hline 5 & $\mathbf{E}$ & M & D & D & D & D & I & & $P$ & E & $\mathbf{E}$ & M & D & D & D & D & $\mathbf{P}$ & & D & D & D & & & & D I & D & 3 & 3 & 2 & 17 \\
\hline 6 & D & D & $\mathbf{P}$ & $\mathbf{E}$ & E & M & I & & D & D & D & $\mathbf{P}$ & $\mathbf{P}$ & $\mathbf{P}$ & $\mathbf{E}$ & D & E & $\mathbf{E}$ & D & D & D & D & D & D I & D & E & 4 & 6 & 1 & 14 \\
\hline 7 & $\mathbf{P}$ & $\mathbf{E}$ & E & E & E & D & L & & D & D & D & $\mathbf{P}$ & $\mathbf{P}$ & $P$ & $\mathbf{E}$ & D & $E$ & $\mathbf{E}$ & $\mathbf{E}$ & $\mathrm{D}$ & $\mathrm{D}$ & D & D & D & $\mathbf{P}$ & & & 8 & & 12 \\
\hline 8 & $\mathrm{E}$ & M & D & D & D & D & $\mathrm{I}$ & 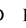 & D & D & $\mathbf{P}$ & D & $\mathbf{P}$ & $P$ & $\mathbf{E}$ & D & D & D & D & $\mathrm{D}$ & $\mathrm{D}$ & D & D & $\mathrm{P}$ & $P \quad$ & I & 5 & 2 & 1 & 17 \\
\hline 9 & M & D & D & $\mathbf{E}$ & E & D & $\mathrm{L}$ & & & D & $\mathbf{P}$ & $\mathbf{P}$ & $\mathbf{P}$ & $\mathrm{D}$ & D & $\mathrm{D}$ & D & D & $\mathbf{E}$ & $\mathrm{M}$ & $\mathrm{D}$ & D & D & D & & & & & & 17 \\
\hline 10 & $\mathrm{E}$ & $\mathrm{E}$ & E & $\mathrm{E}$ & E & D & I & & D & D & $\mathrm{P}$ & $\mathrm{M}$ & $\mathrm{M}$ & D & D & $\mathbf{P}$ & $\mathrm{E}$ & $\mathrm{E}$ & $\mathrm{M}$ & $\mathrm{D}$ & $\mathrm{D}$ & D & $\mathrm{D}$ & D 1 & $\mathrm{P}$ & & & 7 & 3 & 12 \\
\hline 11 & & & $M$ & $\mathrm{D}$ & $\mathrm{D}$ & & & & & $\overline{\mathrm{D}}$ & $\mathrm{D}$ & D & $\mathrm{D}$ & $\mathrm{D}$ & $\mathrm{D}$ & $\mathrm{D}$ & $\mathrm{D}$ & $\mathrm{D}$ & $P$ & $\mathrm{D}$ & $\mathrm{D}$ & $\mathrm{D}$ & & $\bar{E}$ & $E$ & & & & & \\
\hline 12 & $\mathbf{E}$ & $\mathbf{E}$ & D & D & D & D & $\mathrm{L}$ & 1 & $P$ & $\mathbf{E}$ & $\mathbf{E}$ & M & D & $\mathrm{D}$ & E & $\mathbf{E}$ & E & $\mathbf{E}$ & $\mathrm{D}$ & $\mathrm{D}$ & $\mathbf{P}$ & E & E & D I & D I & & 2 & 10 & 1 & 12 \\
\hline 1. & $\mathbf{P}$ & M & $\mathbf{E}$ & M & $\mathrm{M}$ & D & I & & D & D & $\mathrm{D}$ & D & D & $\mathrm{D}$ & $\mathrm{D}$ & $\mathrm{D}$ & D & $\mathbf{P}$ & D & $\mathbf{E}$ & $\mathrm{D}$ & D & $\mathbf{P}$ & E & $\mathbf{E}$ & & & 4 & & 15 \\
\hline 1 & D & $P$ & $\mathbf{E}$ & D & D & D & $\mathrm{I}$ & & D & D & D & D & D & $\mathrm{D}$ & D & $P$ & $\mathrm{E}$ & $\mathrm{E}$ & D & $\mathrm{D}$ & $\mathrm{D}$ & $E$ & M & D I & D & $\mathrm{H}$ & 2 & 5 & 1 & 17 \\
\hline 15 & E & $\mathrm{E}$ & M & $\mathrm{M}$ & D & D & $\mathrm{L}$ & & D & D & $\mathrm{D}$ & D & D & D & $\mathrm{D}$ & D & D & $\mathrm{D}$ & $\mathrm{E}$ & $\mathrm{E}$ & $\mathrm{M}$ & D & $\mathrm{E}$ & E $\mathrm{I}$ & M I & D & 0 & 6 & 4 & 15 \\
\hline 16 & P & $\mathbf{E}$ & M & D & D & D & I & I & D & D & D & D & D & $\mathrm{D}$ & $\mathbf{E}$ & $\mathbf{E}$ & E & $\mathbf{P}$ & $\mathbf{E}$ & $\mathbf{E}$ & $\mathbf{E}$ & M & E & M I & D I & D & 2 & 8 & 3 & 12 \\
\hline 17 & & & M & D & D & D & I & & D & D & D & D & D & $\mathrm{D}$ & D & D & D & $\mathbf{P}$ & $\mathbf{E}$ & $\mathbf{E}$ & $\mathrm{D}$ & D & $\mathrm{E}$ & E & E N & & & 7 & & 15 \\
\hline 18 & $\mathbf{P}$ & $\mathbf{E}$ & D & D & D & D & $\mathrm{I}$ & & D & D & D & D & D & $\mathrm{D}$ & $\mathbf{P}$ & $\mathbf{E}$ & E & $\mathbf{E}$ & $\mathbf{E}$ & $\mathbf{E}$ & $\mathrm{D}$ & D & $\mathbf{P}$ & E & E & & 3 & 9 & 0 & 13 \\
\hline 19 & $\mathrm{E}$ & $\mathrm{E}$ & $\mathrm{M}$ & $\mathrm{E}$ & D & D & L & & D & D & D & D & $P$ & $\mathrm{P}$ & $\mathrm{M}$ & $\mathrm{M}$ & M & D & M & $\mathrm{M}$ & $\mathrm{D}$ & D & $P$ & $\mathrm{E}$ & $\mathrm{E}$ & & & 6 & & 10 \\
\hline 20 & & & & $\mathrm{D}$ & & $\mathrm{D}$ & & & & $\mathrm{D}$ & & & $\mathrm{D}$ & & & & & & $\mathrm{D}$ & & & & & & & & & & & \\
\hline 21 & D & & M & $\mathrm{E}$ & D & D & I & & D & $\mathrm{E}$ & $\mathrm{E}$ & D & M & $\mathbf{P}$ & $\mathrm{E}$ & $\mathrm{E}$ & $\mathrm{E}$ & $\mathbf{E}$ & M & $\mathrm{D}$ & $\mathrm{D}$ & D & D & E & M & & & 8 & & 10 \\
\hline 22 & $\mathrm{E}$ & & M & M & $\mathrm{M}$ & D & & & D & $\mathbf{P}$ & D & D & $\mathbf{P}$ & $\mathrm{E}$ & $\mathbf{E}$ & $\mathbf{E}$ & E & $\mathbf{E}$ & $\mathrm{E}$ & $\mathrm{M}$ & $\mathrm{D}$ & $P$ & $\mathrm{E}$ & E & $\mathrm{E}$ & & & 11 & & \\
\hline 23 & F & & $\mathbf{E}$ & D & D & D & I & & $E$ & $\mathbf{E}$ & $\mathbf{E}$ & E & $\mathbf{E}$ & $\mathbf{E}$ & $\mathrm{M}$ & $\mathrm{D}$ & D & $\mathbf{P}$ & $\mathbf{E}$ & $\mathbf{E}$ & $\mathbf{E}$ & D & D & D 1 & D & & & 2 & & 10 \\
\hline 24 & $P$ & $\mathbf{E}$ & D & $\mathbf{E}$ & M & D & I & & D & D & $\mathrm{D}$ & D & $\mathbf{P}$ & $\mathbf{P}$ & $\mathbf{E}$ & $\mathbf{E}$ & E & $\mathbf{E}$ & $\mathbf{E}$ & $\mathbf{E}$ & $\mathrm{M}$ & D & $\mathbf{P}$ & & E I & & 4 & 11 & 2 & 8 \\
\hline 25 & $\mathbf{P}$ & $\mathbf{P}$ & D & D & D & D & & & D & D & D & $\mathbf{P}$ & $\mathbf{P}$ & $\mathbf{E}$ & $\mathbf{E}$ & $\mathbf{E}$ & E & $\mathbf{E}$ & $\mathbf{E}$ & $\mathrm{M}$ & $\mathrm{M}$ & D & D & E & M & & 4 & 7 & 4 & 10 \\
\hline 26 & D & & $\mathrm{M}$ & $\mathrm{M}$ & D & D & I & & & D & $\mathrm{D}$ & $\mathbf{P}$ & E & $\mathbf{E}$ & $\mathbf{E}$ & & E & $\mathbf{E}$ & D & D & $\mathrm{D}$ & D & $\mathrm{D}$ & $\mathrm{P}$ & $\mathrm{E}$ & & & 8 & & 12 \\
\hline 27 & & $P$ & $\mathrm{E}$ & $\mathrm{E}$ & D & D & I & & D & F & $\mathrm{E}$ & E & $\mathbf{E}$ & $\mathbf{E}$ & $\mathbf{E}$ & & D & D & D & D & D & $P$ & $\mathrm{E}$ & E & E & & & 13 & 1 & 9 \\
\hline 28 & D & D & $\mathrm{D}$ & D & D & D & I & & D & $\mathbf{P}$ & $\mathbf{E}$ & E & E & $\mathbf{E}$ & E & E & $\mathrm{E}$ & M & $\mathrm{D}$ & $\mathrm{D}$ & $\mathrm{D}$ & D & D & E 1 & E & & & 9 & 1 & 14 \\
\hline 29 & $\mathrm{E}$ & $\mathrm{E}$ & $\mathrm{E}$ & D & D & D & & & & $\mathrm{E}$ & $\mathrm{M}$ & $\mathrm{E}$ & E & $\mathrm{M}$ & D & & D & $\mathbf{P}$ & $\mathrm{E}$ & $\mathrm{E}$ & $\mathrm{M}$ & D & D & E & $\mathrm{E} \quad \mathrm{N}$ & & 2 & 10 & & \\
\hline 30 & & & & & & $\mathrm{E}$ & & & & $\mathrm{D}$ & & E & & & & & $\mathrm{D}$ & & 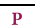 & & & & & & & & & 14 & & \\
\hline 31 & $M$ & D & $\mathrm{D}$ & & $\mathbf{P}$ & . & I & & D & $\mathrm{D}$ & $\mathbf{P}$ & $M$ & D & $\mathrm{D}$ & M & $\mathrm{D}$ & E & $\mathrm{E}$ & $M$ & M & E & E & $\mathrm{E}$ & E 1 & $M$ & D & & 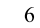 & & y \\
\hline 32 & $M$ & & $\mathrm{D}$ & $\mathbf{P}$ & D & $\mathbf{P}$ & & & D & $\mathbf{P}$ & $\mathrm{D}$ & D & D & E & 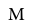 & $\mathrm{D}$ & D & $\mathrm{D}$ & $\mathrm{D}$ & $\mathrm{E}$ & $\mathrm{E}$ & $\mathbf{P}$ & $\mathrm{E}$ & E & $\mathrm{E}$ & & 4 & 7 & & 11 \\
\hline & & D & $\mathrm{D}$ & D & D & $\mathbf{P}$ & r & & P & P & $\mathrm{P}$ & 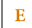 & $\mathrm{E}$ & E & $\mathrm{E}$ & $\mathbb{E}$ & E & $\mathrm{E}$ & E & $\mathrm{E}$ & $\mathrm{M}$ & & D & D & $\mathrm{E}$ & & & 12 & 2 & 6 \\
\hline 34 & E & $\mathrm{E}$ & $\mathrm{E}$ & $\mathrm{E}$ & M & D & I & & D & E & E & $\mathrm{E}$ & D & D & D & $\mathrm{P}$ & $\mathrm{E}$ & $\mathrm{E}$ & E & D & $\mathrm{D}$ & $\mathrm{E}$ & $\mathrm{E}$ & M & E & & 1 & 14 & 2 & \\
\hline 3 & F & & $F$ & E & M & $\mathrm{D}$ & I & & D & $\mathbf{E}$ & $\mathbf{E}$ & D & D & $\mathbf{P}$ & $\mathrm{M}$ & & E & $M$ & $\mathrm{D}$ & $\mathrm{D}$ & $\mathbf{P}$ & P & $\mathrm{D}$ & D I & D & & 3 & 8 & & 11 \\
\hline 3 & & & E & $\mathrm{E}$ & $\mathrm{E}$ & $\mathrm{F}$ & $N$ & & D & D & $\mathbf{P}$ & $P$ & $P$ & $P$ & $\mathrm{D}$ & & $\mathrm{E}$ & $\mathrm{E}$ & $\mathrm{E}$ & $\mathrm{E}$ & $\mathrm{D}$ & $\mathrm{E}$ & $\mathrm{E}$ & $\mathrm{E}$ & M & & 4 & 3 & 3 & 5 \\
\hline 3 & & E & $\mathrm{E}$ & $\mathrm{E}$ & $\mathrm{E}$ & $M$ & & & D & D & $\mathbf{P}$ & M & D & E & $\mathrm{D}$ & $\mathbb{E}$ & E & $\mathrm{E}$ & E & $\mathrm{D}$ & $\mathrm{P}$ & D & $\mathrm{D}$ & D & D & & & 10 & & 1 \\
\hline 3 & 4 & M & $\mathrm{D}$ & D & D & $\mathrm{D}$ & I & & D & D & $\mathrm{D}$ & $\mathrm{E}$ & D & $\mathrm{P}$ & $\mathrm{D}$ & $\mathbf{P}$ & D & $\mathrm{D}$ & $\mathrm{D}$ & $P$ & $\mathrm{D}$ & $P$ & $\mathrm{E}$ & $\mathrm{E}$ & $\mathrm{E}$ & & 4 & 6 & 1 & 12 \\
\hline 39 & E & $\mathrm{E}$ & $\mathrm{E}$ & D & D & P & & $\mathrm{E}$ & E & M & $\mathrm{M}$ & D & D & P & D & & D & $\mathrm{D}$ & $\mathrm{E}$ & $\mathrm{E}$ & $\mathrm{M}$ & E & E & E & $\mathrm{E}$ & & 2 & 11 & 4 & 8 \\
\hline 4 & M & & $\mathrm{E}$ & M & E & E & & & $\mathrm{E}$ & M & $\mathrm{E}$ & $\mathrm{E}$ & $\mathrm{E}$ & E & D & & E & $\mathrm{E}$ & E & E & $\mathbf{E}$ & M & $M$ & D 1 & D & & 1 & 15 & 6 & 3 \\
\hline & & D & D & $P$ & $\mathbf{P}$ & $\mathbf{P}$ & & & $\mathrm{E}$ & D & $\mathrm{D}$ & D & D & E & $\mathrm{E}$ & $\mathrm{M}$ & D & $\mathrm{D}$ & D & $\mathrm{D}$ & $\mathrm{D}$ & D & D & D & P & & & 6 & & 12 \\
\hline 4 & $\mathrm{E}$ & & $\mathrm{D}$ & D & E & $\mathrm{E}$ & 1 & & $\mathrm{E}$ & D & $\mathrm{D}$ & $\mathrm{E}$ & $\mathrm{E}$ & M & $\mathrm{E}$ & $\mathrm{D}$ & D & $\mathrm{D}$ & $\mathrm{E}$ & $\mathrm{E}$ & $\mathrm{M}$ & D & $\mathrm{D}$ & $P$ & $\mathrm{E}$ & & & 2 & 3 & \\
\hline & $\mathrm{E}$ & $\mathrm{E}$ & $\mathrm{D}$ & D & E & E & & & M & D & $\mathrm{p}$ & D & $\mathrm{F}$ & $\mathrm{M}$ & $\mathrm{D}$ & $P$ & $p$ & $\mathrm{M}$ & $M$ & $\mathrm{E}$ & $\mathrm{E}$ & $\mathrm{E}$ & $\mathrm{M}$ & D & D & & & 0 & 5 & \\
\hline 44 & E & E & M & D & E & E & & & $\mathrm{E}$ & D & $\mathrm{D}$ & E & E & E & $M$ & $\mathrm{D}$ & D & E & E & $\mathrm{E}$ & $\mathbf{E}$ & D & D & E & E & & 0 & 16 & 2 & . \\
\hline 45 & D & D & $\mathrm{D}$ & D & $\mathbf{P}$ & E & & & $E$ & $\mathbf{E}$ & $\mathbf{E}$ & E & $\mathbf{E}$ & E & $\mathrm{D}$ & $\mathrm{D}$ & $\mathrm{D}$ & $\mathrm{D}$ & $\mathbf{P}$ & E & $\mathbf{E}$ & E & $\mathrm{M}$ & E & $\mathrm{E}$ & & 2 & 14 & 1 & \\
\hline 4 & & & 2 & & D & & & & 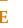 & D & $\mathrm{D}$ & D & D & E & . & 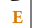 & $\mathrm{E}$ & $\mathrm{E}$ & $M$ & $\mathrm{M}$ & $\mathbf{E}$ & E & M & D & D & & & $z$ & & \\
\hline 4 & $\mathrm{E}$ & $\mathrm{D}$ & $\mathrm{P}$ & $P$ & $\mathrm{D}$ & $\mathrm{P}$ & 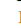 & & $\mathrm{E}$ & $\mathrm{E}$ & $\mathrm{E}$ & $\mathrm{E}$ & $\mathrm{E}$ & E & $\mathrm{D}$ & $\mathbf{P}$ & D & $\mathrm{D}$ & $\mathrm{E}$ & $\mathrm{E}$ & E & $\mathrm{D}$ & $\mathrm{D}$ & D & $\mathrm{E}$ & & 4 & 8 & 0 & \\
\hline 48 & $\mathbf{E}$ & M & $\mathrm{D}$ & D & D & $\mathbf{P}$ & & & & $\mathbf{E}$ & $F$ & $\mathrm{E}$ & E & E & E & $M$ & E & E & E & $\mathrm{E}$ & $\mathbf{E}$ & M & $\mathrm{M}$ & D & D & & & 5 & 4 & \\
\hline 49 & $\mathrm{P}$ & & $\mathrm{D}$ & $\mathrm{D}$ & & $\mathrm{F}$ & & & $\mathrm{E}$ & 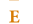 & & $M$ & & 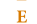 & & & 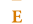 & & & & & & & & & & 2 & 15 & 3 & \\
\hline
\end{tabular}

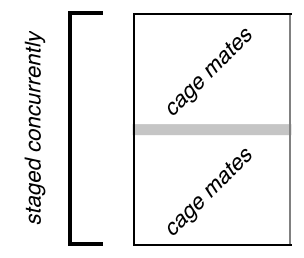

742 Table 1: Estrous cycling in example animals

$743 \quad$ Proestrus $(P)$, estrus $(E)$, metestrus $(M)$, and diestrus $(D)$ 